\title{
TEMPAT KETIGA KOTATUA JAKARTA SEBAGAI GERBANG INTEROGATIF TERHADAP KEMAJUAN KOTATUA
}

\author{
Ferel Putra ${ }^{1)}$, Tatang Hendra Pangestu ${ }^{2)}$ \\ 1)Program Studi S1 Arsitektur, Fakultas Teknik, Universitas Tarumanagara, ferelputra@gmail.com \\ 2) Program Studi S1 Arsitektur, Fakultas Teknik, Universitas Tarumanagara, tatang_pangestu@hotmail.com
}

Masuk: 14-07-2020, revisi: 28-07-2020, diterima untuk diterbitkan: 24-09-2020

\begin{abstract}
Abstrak
Kotatua Jakarta merupakan tempat yang sangat ramai dikunjungi banyak pengunjung dari daerah yang beraneka ragam. Disamping itu Kotatua merupakan sebuah tempat yang juga memiliki penduduk asli dalam jumlah yang sedikit. Hal ini membuat Kotatua menjadi sebuah tempat yang memiliki tingkat keberagaman yang tinggi. Maka, perlu dibuatlah sebuah tempat ke-3 yang bersifat mempersatukan masyarakat yang memiliki latar belakang berbeda, agar terjadilah interogasi yang mendewasakan yang dapat menjadi cikal bakal pertumbuhan masyarakat Indonesia yang baik. Proyek ini juga memiliki tujuan lain untuk meningkatkan kualitas Kotatua sebagai kawasan turisme dengan membangun sebuah pusat informasi yang berguna bagi pengunjung, dan pusat komunitas yang berguna bagi para pekerja turisme disana. Gerbang Interogatif Kotatua Jakarta berbicara tentang ruang interogatif yang membuat manusia bertumbuh yang berfokus dalam pengadaan ruang-ruang yang memicu adanya interaksi sosial yang berujung pada interogasi antar manusia yang mendewasakan, tentunya sambil menyampaikan informasi turisme Kotatua maupun Jakarta pada umumnya, dan melestarikan serta meningkatkan ekonomi komunitas yang sudah ada sebelumnya.
\end{abstract}

\section{Kata kunci: interogasi; keberagaman; mendewasakan}

\begin{abstract}
Kotatua Jakarta is a very crowded place visited by many visitors from many diverse areas. Other than that, Kotatua is also a home for some people, a place where they build their lives. This makes Kotatua becomes a high diversity place. Therefore, it is necessary to make a third place that unites people from different backgrounds for the sake of good Indonesian society growth by providing an interrogative place where people can meet, socialize, and interrogate their own lives by seeing other people's lives. In addition, the project also has another goal, which is to improve the quality of Kotatua as a tourism area by building an information center that is useful for visitors, as well a community center that is useful for tourism workers there. Kotatua Jakarta Interrogative Gate talks about interrogative space for human growth that focuses on the provision of spaces that trigger social interaction that results in interrogation between human beings so they can become more open minded, of course while conveying information on both Kotatua and Jakarta tourism and preserving and enhancing the economy of pre-existing communities, as a gate that is opened for everybody.
\end{abstract}

Keywords: diversity; interrogate; open minded

\section{PENDAHULUAN}

Perkembangan teknologi komunikasi (internet) memberikan banyak dampak positif bagi kehidupan manusia. Hal tersebut meliputi meningkatnya kemudahan manusia untuk mendapatkan informasi dan berkomunikasi serta menjalin relasi dengan siapapun, kapanpun, dan dimanapun (Salangkas, 2019). Kecepatan pertumbuhan dan perkembangan teknologi komunikasi (internet) diimbangi dengan kecepatan kenaikan pengguna internet itu sendiri. 
Menurut data yang diperoleh oleh Lembaga Statistik Internet World Stats (2019), perkembangan internet yang sangat besar terjadi dalam kurun waktu 2,5 dekade terakhir yaitu mencapai $25000 \%$.

Namun ironinya, manusia-manusia yang banyak menggunakan internet mengalami banyak masalah yang tentunya tidak dialami oleh manusia-manusia yang lahir di jaman sebelumnya. Mereka menjadi manusia yang sulit berinteraksi secara langsung, juga menjadi manusia yang indivdualis (Graham, 2014). Masalah-masalah ini perlu diselesaikan demi terciptanya mental generasi penerus bangsa yang lebih baik. Masalah-masalah diatas timbul karena manusia secara tidak sadar sudah terlalu banyak tenggelam dalam dunia internet yang bebas tanpa batas dan tidak lagi terbiasa dan memiliki kesempatan untuk tumbuh didalam sebuah komunitas nyata yang beragam, sebuah komunitas yang berisi manusia-manusia yang berbeda, yang tumbuh Bersama, dan yang saling mengkritik pendapat satu sama lain secara langsung (Bhabha, 1994).

Salah satu tempat di Indonesia yang marak dengan isu tersebut adalah Pulau Jawa termasuk Jakarta yaitu Ibukota Indonesia sendiri (Pratomo, 2018). Melihat permasalahan yang terjadi, maka perlu dibuatnya sebuah tempat yang dapat menjadi wadah pertemuan manusia-manusia yang beragam identitasnya sehingga manusia-manusia pengguna internet ini dapat lagi menumbuhkan identitasnya di sebuah lingkungan yang nyata. Ide tersebut dapat diwujudkan di dalam sebuah third place, yaitu tempat yang mewadahi kegiatan manusia selain kegiatan beristirahat (first place) dan tempat kerja (second place). Juga sebuah tempat yang memiliki tingkat kepadatan dan keberagaman yang tinggi. Ciriciri di atas dijumpai di sebuah kawasan yang bernama Kawasan Kotatua Jakarta. Kotatua Jakarta merupakan sebuah kawasan yang terletak di Daerah Administrasi Jakarta Utara dan Jakarta barat, daerah administrasi terpadat yang dimiliki Jakarta. Kawasan ini merupakan salah satu kawasan wisata yang ramai dikunjungi wisatawan yang beragam baik internasional maupun domestik (Poerwanto, 2019). Walaupun kawasan ini sudah menjadi sebuah third place bagi seluruh Jakarta bahkan bagi wisatawan, namun tempat ini tetap membutuhkan wadah pertemuan manusia yang beragam, berupa sebuah bangunan visitor center sambil menjawab kebutuhan Kotatua Jakarta yang lainnya terkait dengan kepariwisataan.

\section{KAJIAN LITERATUR}

\section{Teori Tempat Ketiga (Third Place)}

Third place adalah tempat berkumpul informal yang digunakan manusia selepas kegiatandi rumah (first place) dan di tempat kerja (second place) (Oldenburg, 1989). Dalam bukunya, Ray Oldenburg menjelaskan berbagai kualitas dari third place:

a. Neutral Ground

Kota memiliki potensi akan keberagaman asosiasi yang dapat dinikmati oleh lingkungannya. Maka dari itu diperlukan sebuah tapak netral untuk mewadahi kegiatan tersebut. Netral yang dimaksud dalam hal ini adalah keadaan dimana semua orang dapat datang dan pergi sesuai dengan keinginan mereka tanpa ada halangan.

b. The third place as a leveler

Sebuah third place adalah sebuah tempat yang inklusif. Third place menerima siapapun yang mau datang dengan pandangan yang sama yaitu sebagai manusia, terlepas dari pekerjaan, status, dan berbagai macam kondisi kehidupan yang lain.

c. Conversation is the main activity

Tujuan utama dari dibentuknya sebuah third place adalah mewadahi kebutuhan komukasi antar penduduk. Komunikasi yang diharapkan adalah komunikasi yang bebas namun tetap perlu memperhatikan beberapa norma-norma seperti saling menghormati dan menghargai. 


\section{d. Accessibility and accommodation}

Salah satu sifat dari third place adalah selalu ada disaat penduduk membutuhkannya secara kelompok maupun personal. Third place merupakan tempat yang mudah diakses oleh siapa saja, dan memungkinkan adanya aktifitas 24 jam. Aktifitas 24 jam ini memberikan kepastian bahwa selalu ada aktifitas dan pelaku aktifitas di tempat tersebut setiap saat.

e. Regulars

Regular yang dimaksud di sini adalah orang-orang yang datang berkala yang membuat sebuah third place menjadi hidup. Regular merupakan daya tarik bagi pendatang baru, yang mungkin juga merupakan pendatang baru pada mulanya. Regular ini berperan untuk memperluas jangkauan sosial suatu third place dengan memungkinkan terbentuknya sebuah world of strangers.

f. Low Profile

Third place tidak boleh menjadi eksklusif dalam hal fungsi maupun desain dan harus menyambut semua orang yang datang. Lebih mengarah ke middle-class profile.

g. Playful

Third place merupakan tempat yang bermain. Arti dari playful di sini adalah fungsi dari third place yang ditujukan untuk mewadahi manusia untuk mendapat hiburan. Segala macam perlakuan pengguna dalam rangka menghibur diri tidak akan di alienasi dan akan selalu diterima.

h. A home away from home

Third place merupakan sebuah tempat yang menjadi rumah ke dua setelah tempat tinggal utamanya yaitu first place.

Third place berperan sebagai sebuah ruang keluarga dari sebuah masyarakat (Living room for a society) dimana manusia benar-benar menjalin relasi dengan manusia lain secara nyata seperti hal nya fungsi ruang keluarga yang terdapat pada tempat tinggal manusia yaitu rumah (Butler, 2016). Third place juga merupakan sebuah tempat dimana adanya blurring perbatasan yang ada antara penduduk kota yang bervariasi, maka terjadi hibridasi akan identitas-identitas yang ada dan mengurangi adanya primordial unity and fixity sehingga masyarakat lebih mengerti mengenai perbedaan yang ada (Bhabha, 1994). Third place biasanya diisi oleh kegiatan menghibur yang menggunakan skill diluar skill manusia yang digunakan untuk bekerja. Hal ini ditunjukkan dari berbagai third place yang bermunculan dalam wujud repair space, music space, dan art space.

\section{Ciri Tempat Ketiga (Third Place)}

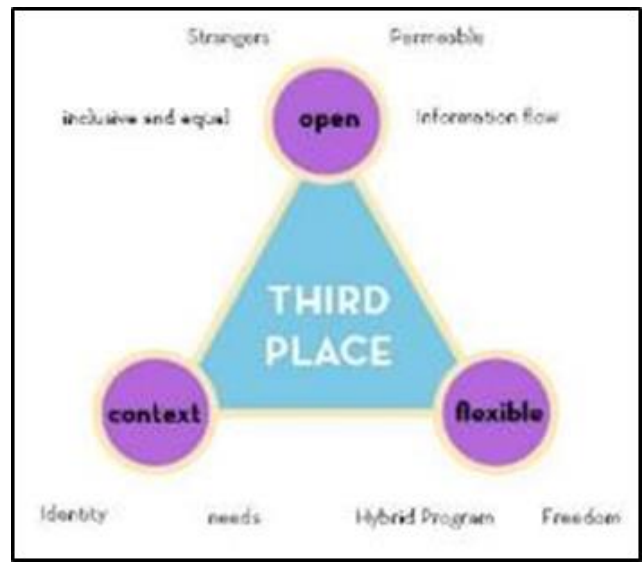

Gambar 1. Third Place

Sumber: Dokumentasi Pribadi, 2020 
Menurut Sutanto (2020) Third place terdiri dari 3 elemen yaitu openness, flexibility, dan contextual. Openness: world of strangers (dipenuhi oleh orang-orang yang tidak saling mengenal), permeable (menyatu dengan trotoar dan ramah pejalan kaki, serta memungkinkan banyak cabang sirkulasi), inclusive and equal (terbuka kepada semua orang), dan terdapat information flow (pengaliran informasi). Flexibility: program hybrid (program gabungan dan beraneka ragam), dan ada kebebasan pengguna (pengguna merasa tidak terkekang). Sementara contextual memiliki kriteria: memiliki identitas kawasan (lokalitas), dan menjawab kebutuhan pengguna.

\section{Identifikasi Tempat Ketiga (Third Place)}

Tabel 1. Identifikasi Third Place

\begin{tabular}{llll} 
Indikator & $1^{\text {st }}$ place & $2^{\text {nd }}$ place & $3^{\text {rd }}$ place \\
\hline Privat-publik & Privat & Semi publik & Publik \\
\hline Kebutuhan & Primer & Sekunder & Tersier \\
\hline Identitas & My identity & My company's identity & Mine \& yours \\
\hline Sifat & Relaxed & Strict & Playful \\
\hline Durasi & More & Most & Less \\
\hline Keberagaman & Tidak bervariasi & Komunitas tertentu & Vibrant \\
\hline Peraturan & My rule & Your rule & Our rule \\
\hline
\end{tabular}

Sumber: Dokumentasi Pribadi, 2020

\section{Teori Open Architecture}

Open architecture berawal dari istilah yang terdapat dalam dunia kommputer, yang mengacu pada sebuah sistem komputer yang tidak kaku, namun dirancang sedemikian rupa sehingga dapat memungkinkan pengguna untuk melakukan modifikasi, ekstensi, dan penyesuaian, sesuai dengan kebutuhan (Levison, 2017). Open Architecture dalam dunia arsitektur mengacu kepada arsitektur yang customizable, dan fleksibel mengikuti kebutuhan para pengguna bangunannya. Arsitektur itu sendiri merupakan sebuah teknologi, terdiri dari banyak bagian. Bagian-bagian tersebut harus bisa disesuaikan dengan penggunanya sehingga dapat disebut sebagai open architecture. Namun, open architecture juga harus memiliki fungsi yang pasti dan rigid sebagai kerangka utama dari keseluruhan program yang ada sehingga modifikasi, dan adaptasi yang diperhitungkan tidak dapat dianggap $100 \%$.

Third place merupakan sebuah tempat yang dikunjungi oleh orang-orang yang beraneka ragam. Perbedaan identitas seperti halnya budaya, suku, agama, dan ras, dan lain-lain membentuk perilaku dan aktivitas dan kebutuhan manusia yang berbeda-beda dengaan tingkat keragaman yang tinggi (Oldenburg, 1989). Third place merupakan sebuah tempat dimana pembauran itu terjadi sehingga arsitektur third place harus dibuat open sehingga bisa memenuhi kebutuhan yang berbeda-beda tersebut.

\section{METODE}

\section{Observasi Jiwa Kotatua Jakarta}

Pertama-tama hal yang dilakukan adalah survey lokasi secara langsung (on site) maupun tidak langsung (online research). Hal yang kemudian dilakukan adalah pencatatan hal-hal yang menjadi identitas/ciri khas Kotatua itu sendiri berdasarkan kedua cara observasi tersebut. 


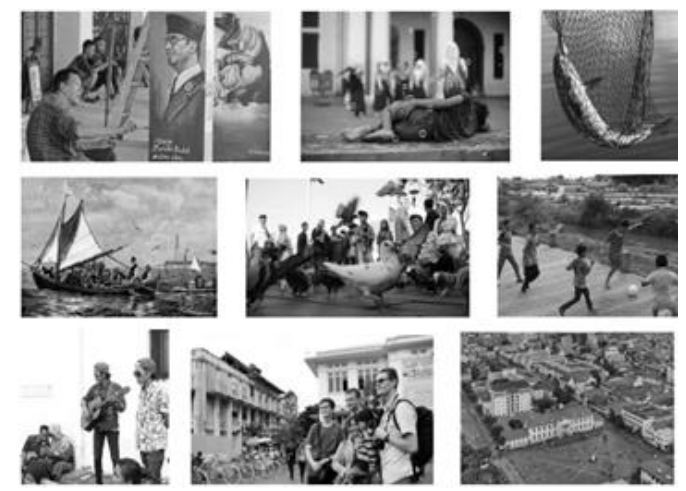

Gambar 2. Jiwa Kotatua Jakarta

Sumber: google.com, Dokumentasi Pribadi, 2020

Dari data yang didapat, maka yang dapat diperhatikan adalah:

a. Terdapat beberapa jenis golongan manusia. Golongan pekerja wisata (musisi jalanan, pelukis, tour guide, patung, fotografer), golongan pendatang (wisatawan asing maupun lokal, dan penduduk dari luar area Kotatua), dan penduduk Kotatua itu sendiri yang menjalani kehidupan kesehariannya di sana termasuk bermain bola dan berolahraga.

b. Kawasan merupakan kawasan yang menarik dan memiliki identitas yaitu terdapat bangunan-bangunan bersejarah yang dilindungi hukum.

c. Kawasan sudah merupakan sebuah third place raksasa bagi seluruh penduduk Jakarta. diramaikan oleh berbagai macam golongan, termasuk burung-burung merpati.

d. Walaupun Kotatua tidak sepenuhnya berada dalam kondisi maritim, namun identitas Sunda Kelapa yang menjadi salah satu bagian Kotatua itu sendiri memberikan citra yang sangat kuat. Citra kemaritiman yang mengandung nilai sejarah, mengingat Kotatua ditopang oleh bisnis kelautan pada masa lampau.

e. Walaupun Kotatua sudah menjadi tempat yang ramai dengan berbagai macam peluang usaha, namun hal tersebut belum teratur dan masih banyak gelandangan yang perlu dididik dan di motivasi. Gelandangan tersebut menduduki wajah Kotatua pada siang hari dan beristirahat di bangunan-bangunan cagar budaya yang tidak terurus secara ilegal pada malam hari.

\section{Strategi Desain: Potensi Hubungan}

Selanjutnya, dilakukan pengelompokan manusia yang ada di kawasan ini lalu dipetakan masing-masing kebutuhannya. Tentunya kebutuhan yang berkaitan dengan wilayah Kotatua ini.

a. Gelandangan yaitu tempat hidup; pekerjaan; perbaikan kualitas hidup

b. Pekerja Wisata yaitu tempat bekerja; penghasilan yang didapat dari pengunjung; area komunitas yang membangun antra sesama pekerja wisata

c. Pendatang yaitu hiburan; Informasi turisme (guide); souvenir

\section{Metode Desain}

Dalam proyek ini penulis memilih metode platonic, adaptive, cave yang berasal dari RAW Architecture (Hidayat et al., 2019:47), yang berarti:

a. Platonic: Menggunakan bentuk-bentuk bersudut sehingga menciptakan bentuk yang efisien, ekonomis dan mereduksi material waste. hal ini bertujuan untuk menciptakan bangunan yang kontekstual dan down to earth serta murah dalam hal biaya. Efisiensi ruang menjadi hal yang penting dalam membuat proyek dengan kemungkinan jumlah dan jenis aktivitas yang tinggi di dalamnya. Material waste juga dapat dikurangi untuk membuat bangunan lebih sustainable.

b. Adaptive: Bangunan dibuat dengan tujuan mempertahankan karakter lokal namun 
menjawab tantangan dunia mengenai kemasyarakatan dan kepariwisataan. Adaptive yang dimaksud adalah bangunan menggunakan material dan arsitektur lokal (Belanda) yang dipadukan dengan material dan teknologi struktur serta desain yang baru. Dengan begini keaslian pun dapat dipertahankan namun berpadu dengan hal yang baru. Hal ini dipelopori oleh seorang restorer bangunan Perancis bernama Eugene Viollet Le-Duc.

c. Cave: Cave mengacu kepada proses desain yang bersifat function follows form. Dalam konteks ini, desain diharapkan dapat mengatur perilaku manusia yang ada didalamnya supaya lebih lagi dapat bersosialisasi dengan manusia lain.

\section{DISKUSI DAN HASIL}

\section{Analisis Hubungan Pengguna}

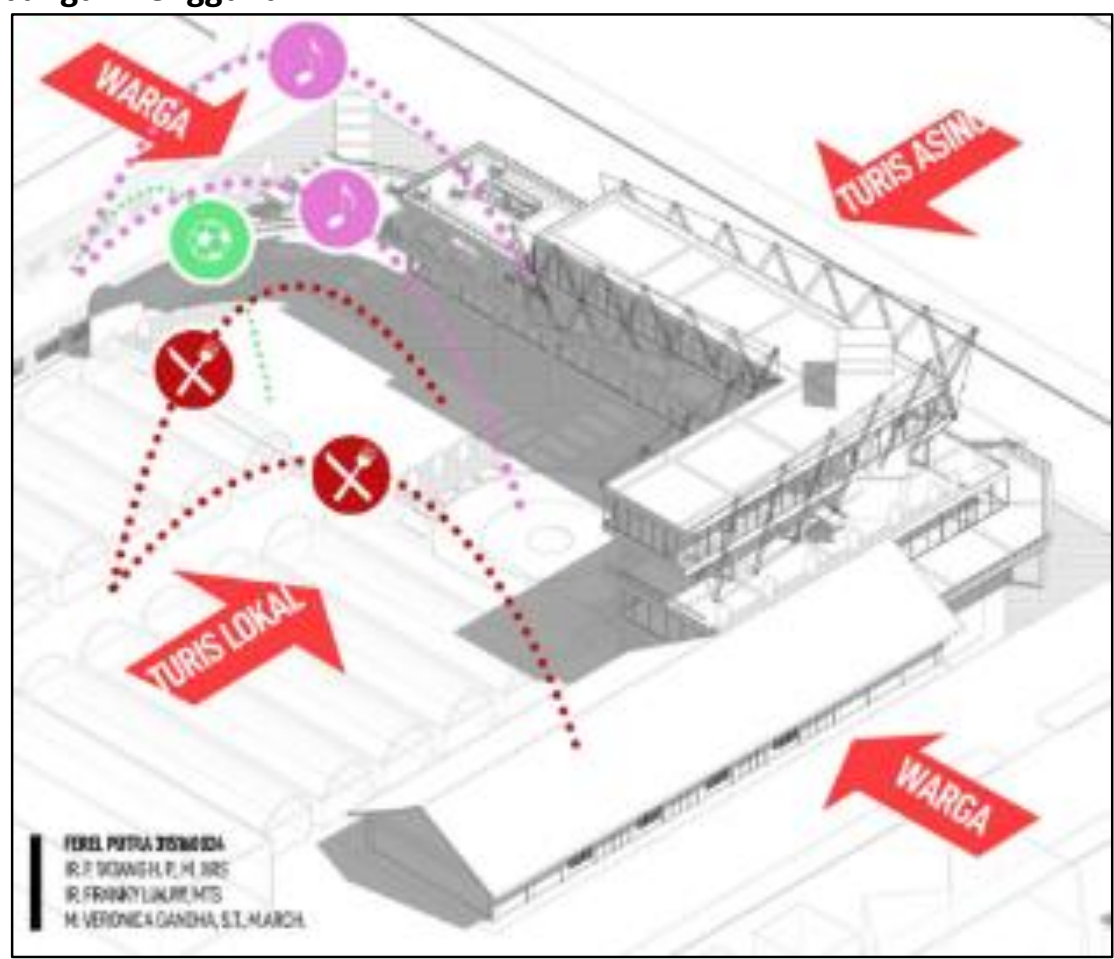

Gambar 3. Hubungan pengguna

Sumber: Dokumentasi Pribadi, 2020

Dari data-data yang sudah diperoleh di Atas, maka dapat diperkirakan hubungan-hubungan apa saja yang berpotensi terjadi namun belum terlaksana. Hubungan-hubungan ini merupakan hubungan yang akan meningkatkan kualitas Kotatua sebagai wilayah ekonomi, dan wilayah wisata. Pekerja wisata mendapat penghasilan dari para pendatang tersebut. Untuk sesama pekerja wisata, mereka dapat saling bertemu dan menginovasi hal-hal baru juga membentuk sebuah komunitas yang sehat. Pendatang mendapat penghiburan dan tentunya informasi dari pekerja-pekerja wisata yang ada di sana melalui suatu hubungan sosial. Gelandangan, dengan terciptanya kondisi sosial yang ramah, teratur, namun memiliki kualitas ekonomi yang tinggi, gelandangan akan mulai termotivasi untuk menjadi pekerja wisata sehingga kualitas hidup meningkat.

\section{Program}

Melihat kemungkinan-kemungkinan yang ada di atas maka muncul usulan program-program yang terdapat dalam proyek ini.

a. Pameran informasi pariwisata

Tempat yang berisi informasi yang dibutuhkan oleh pendatang untuk berwisata di Kotatua/Jakarta. 


\section{b. Function hall}

Digunakan untuk acara kebersamaan, disewa untuk pameran produk lokal/makanan.

c. Edukasi seni spontan dan dinding mural

Tempat memberikan edukasi seni kepada pendatang, juga tempat komunitas mural berekspresi.

d. Pertunjukan ruang terbuka (Outdoor perform area)

Tempat warga bersantai dan bersosialisasi sambil menikmati suasana Kotatua.

e. Stall produk lokal

Dapat disewa oleh pengusaha untuk mempromosikan produk-produk usahanya dalam bentuk barang maupun makanan.

f. Area board game lokal

Tempat pendatang bersantai di area indoor, bersosialisasi dengan pendatang lain sambil bermain permainan daerah.

Segala program dirancang untuk sebisa mungkin mengajak pengunjung untuk berinteraksi, saling bertukar informasi, dan menginterogasi diri sendiri (introspeksi) sambil menyalurkan informasi turisme Kotatua, Jakarta, dan memajukan komunitas serta ekonomi yang sudah ada terlebih dahulu (masyarakat lokal).

\section{Pemilihan Tapak}

Proyek yang akan dibangun merupakan sebuah proyek pelayanan masyarakat yang low profile dan bersifat mengayomi warga yang sudah lebih dahulu ada di sana sebagai penghuni maupun pendatang. Maka dari sekian banyak tapak yang terdapat di Kotatua, dipilihlah tapak yang terbengkalai namun memiliki potensi besar untuk mewadahi program-program di atas.
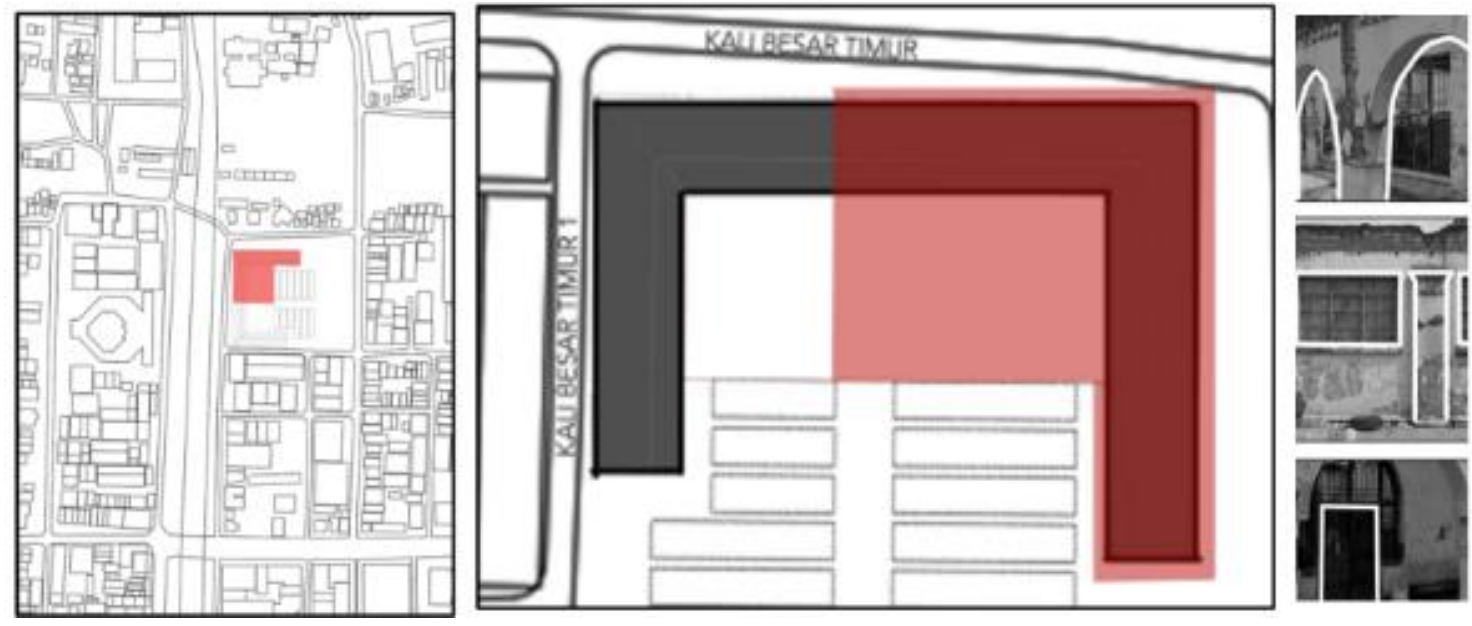

Gambar 4. Lokasi dan Kondisi Eksisting Tapak

Sumber: Dokumentasi Pribadi, 2020

Tapak yang dipilih merupakan tapak dengan bangunan cagar budaya yang sebagiannya dihuni oleh gelandangan. Sebagian area tapak tersebut didominasi oleh lahan parkir terbengkalai yang tidak digunakan. Terletak di Jalan Kali Besar Timur. Tapak yang dipilih pun terletak pada kawasan II cagar budaya Kotatua, dengan bangunannya yang digolongkan kedalam golongan B, yang seperti tertera pada Guidelines Kotatua 2007, area desain tidak boleh merusak fasad namun perubahan fungsi masi dapat dilakukan. Dan sebagaimana tertulis pada UU no. 11 Tahun 2010 mengenai cagar budaya, proses desain harus dilakukan dengan kesadaran penuh untuk melestarikan nilai-nilai sejarahnya. 


\section{Respond To Site}

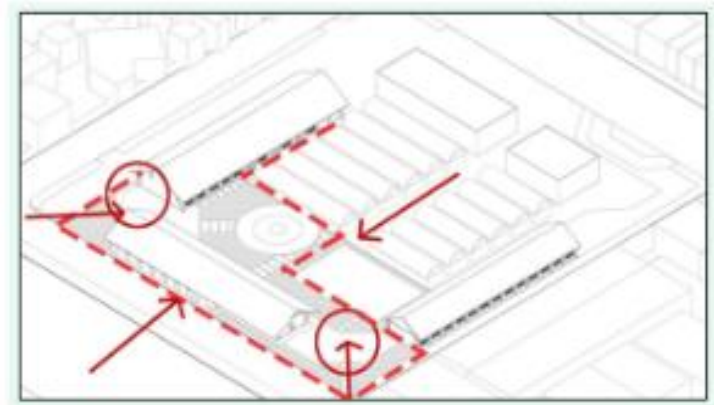

AKSES

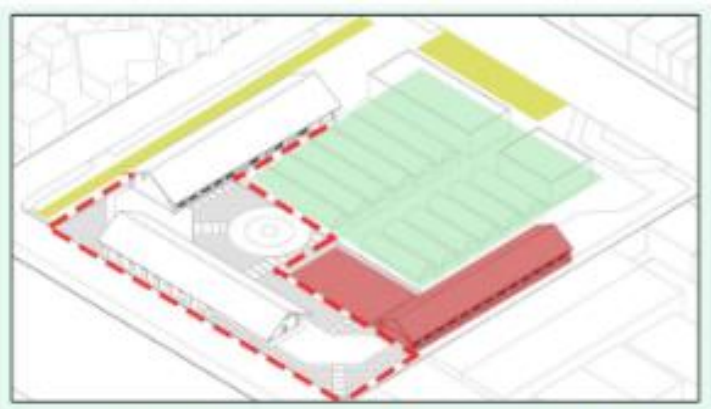

EKSISTING ruang terbuka area warga parkir

Gambar 5. Akses dan Zoning Eksisting Tapak

Sumber: Dokumentasi Pribadi, 2020

Tapak dibentengi oleh bangunan cagar budaya tanpa celah. Melihat arah datang kendaraan dan pejalan kaki, bangunan cagar budaya dibongkar sedikit pada bagian ujungnya supaya lebih welcome. Massa bangunan cagar budaya di utara difungsikan untuk menggantikan fungsi area terbuka eksisting bila suatu hari fungsi berganti. Bagian selatan bangunan dipertahankan untuk tempat tinggal warga

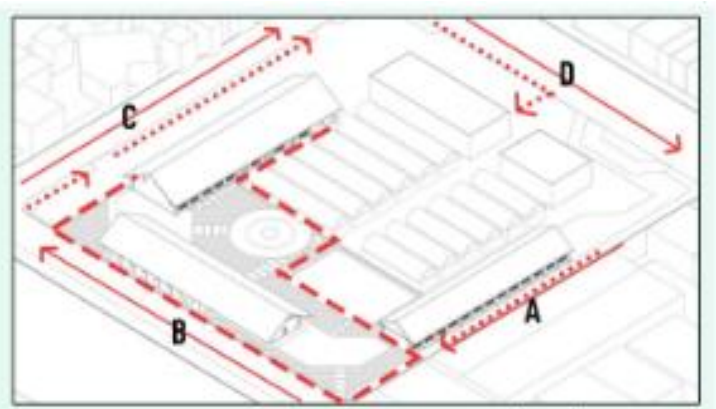

KONDISI JALAN pedestrian

kendaran bermotor

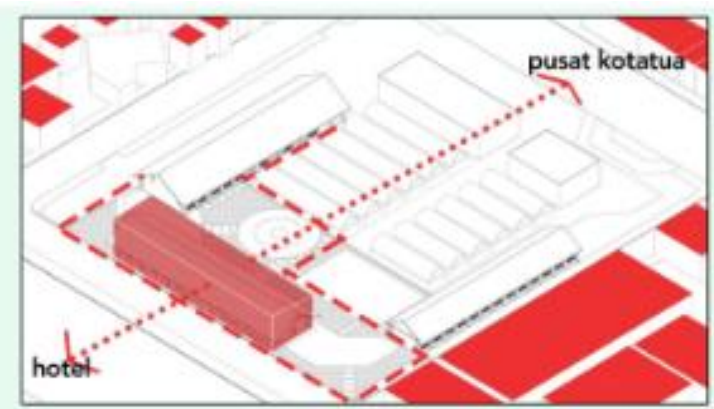

MASSA \& WAIAH

Gambar 6. Kondisi Jalan dan Massa Eksisting

Sumber: Dokumentasi Pribadi, 2020

Jalan A merupakan area yang didominasi oleh pejalan kaki sehingga bagian selatan bangunan dijadikan entrance pejalan kaki. Bukaan yang berada di utara menjadi entrance mobil dikarenakan oleh kondisi eksisting titik tersebut yang dekat dengan tempat parkir. Massa bangunan baru dibuat dengan bentuk dasar rektangular supaya menghargai urban fabric dan figure ground lingkungan sekitarnya. Juga massa bangunan dibuat memiliki 2 wajah yaitu ke pusat Kotatua dan ke arah turis/hotel.

\section{Massing dan Phasing}

Phase 1

Bangunan cagar budaya dibongkar disediakan ruang perform terbuka, massa bangunan lama digunakan untuk pameran informasi turis yang menarik turis untuk datang.

Phase 2

Penduduk yang tinggal sudah memiliki motivasi untuk bekerja, demikianlah ditambahkan massa yang menyatu dengan bangunan tua untuk menambahkan area terbuka yang tersambung dengan jalan. Membuat ruang terbuka yang terbuka dengan jalan tanpa membongkar lebih banyak lagi bangunan cagar budaya yang sudah ada sebelumnya. 


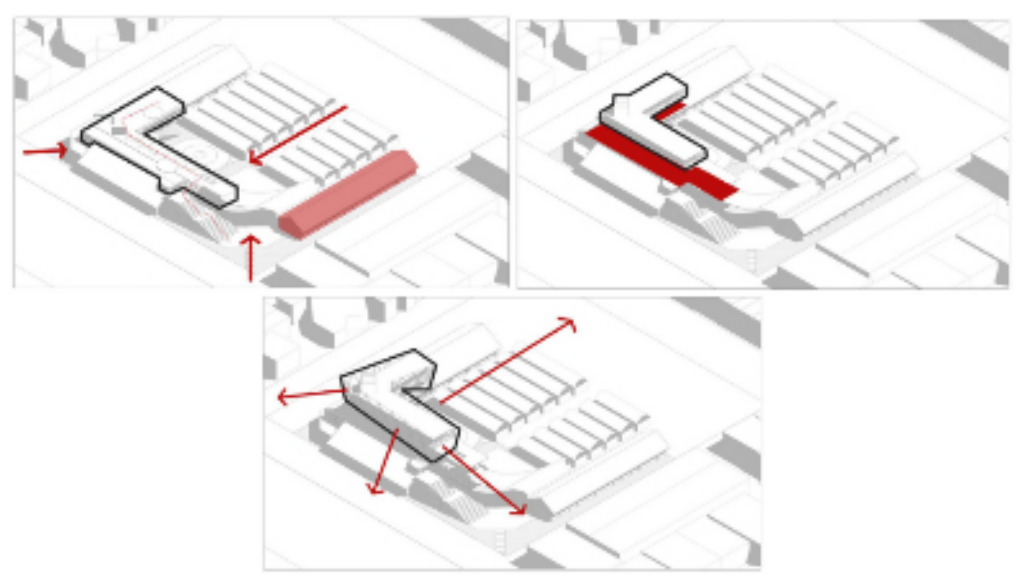

Gambar 7. Proses Massing dan Phasing

Sumber: Dokumentasi Pribadi, 2020

\section{Phase 3}

Area outdoor di lantai 3 digunakan untuk pekerja turisme memamerkan skill mereka sehingga pengunjung tertarik untuk mempelajari seni di lantai 2. Ditambahkan pula massa pelengkap di lantai 4 sebagai tempat bermain game daerah, bersantai di ruang indoor, berbaur, sambil menikmati keindahan Kotatua dari atas untuk melengkapi fungsi third place.

\section{Phase 4}

Skin kaca low-e glass ditambahkan, digunakan menjadi area ekspresi para seniman mural. Membuat bangunan menjadi memiliki identitas lokal yang dapat dilihat dari segala arah.

Proses massing pada proyek ini dipengaruhi oleh 2 faktor. Dari kondisi tapak, dan dari proses pertumbuhan rakyat. selain menyusun massa berdasarkan analisis tapak secara fisik maupun non fisik, proses massing juga didasari oleh fase-fase (phase) perkiraan pertumbuhan masyarakat yang sudah menempati tempat ini terlebih dahulu. Setelah itu konsep tahapan pembangunan pun juga didapat.

\section{Konsep Perancangan: Interrogative Space for Human Growth}

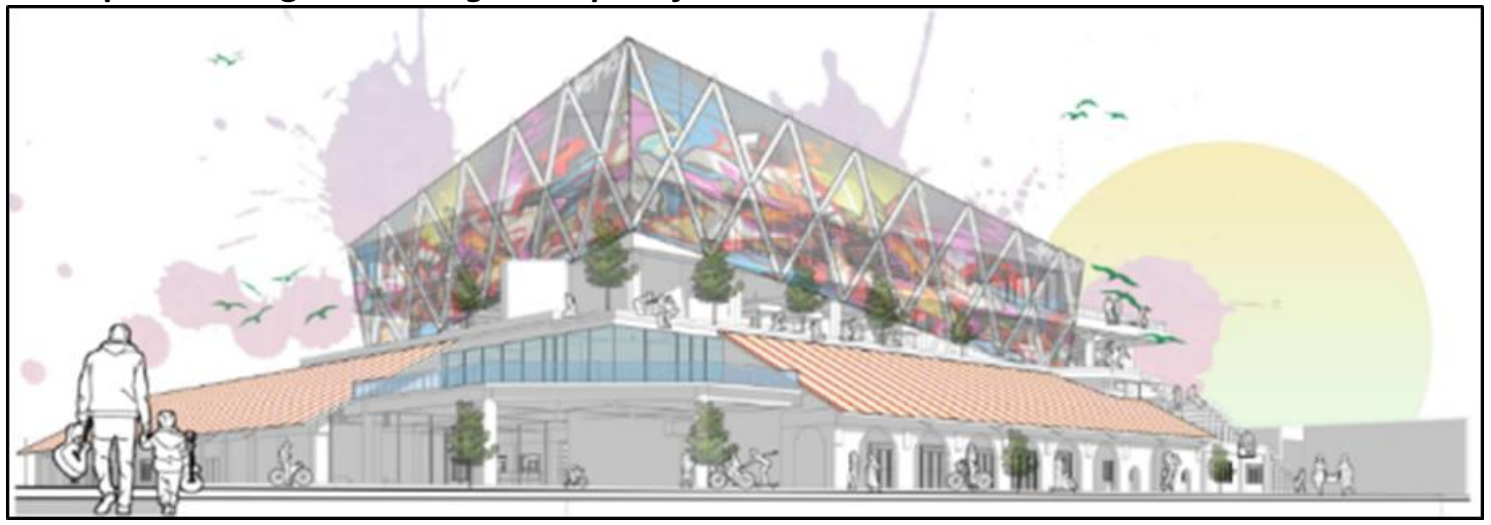

Gambar 8. Perspektif Konseptual

Sumber: Dokumentasi Pribadi, 2020

Secara keseluruhan konsep dari bangunan ini adalah 'kondisi saling mempertanyakan yang membuat manusia bertumbuh'. Pertanyaan yang dimaksud adalah pertanyaan refleksi kepada diri sendiri (introspeksi) setelah pengguna bangunan bertemu dengan sekian jenis manusia dari berbagai latar belakang. Informasi selayaknya tersalurkan Bersama-sama dengan interogasi tersebut melalui interaksi sosial yang terjadi di bangunan ini. Perpaduan bangunan lama dan baru pun berbicara mengenai perbedaan yang membawa sebuah kemajuan, tidak melupakan asal usul Kota Batavia itu sendiri yang dimulai dari Sunda Kelapa, ditandai dengan 
atap yang runcing menunjuk kearah laut Jawa dengan rangka kaca ' $\mathrm{x}$ ' yang terinspirasi dari pola jaring. Kaca mural juga berbicara mengenai identitas masyarakat, sehingga tampak bangunan ini akan terus sesuai dengan kondisi masyarakatnya. Ruang-ruang sedemikian rupa di desain untuk men-trigger interaksi sosial layaknya sebuah third place.

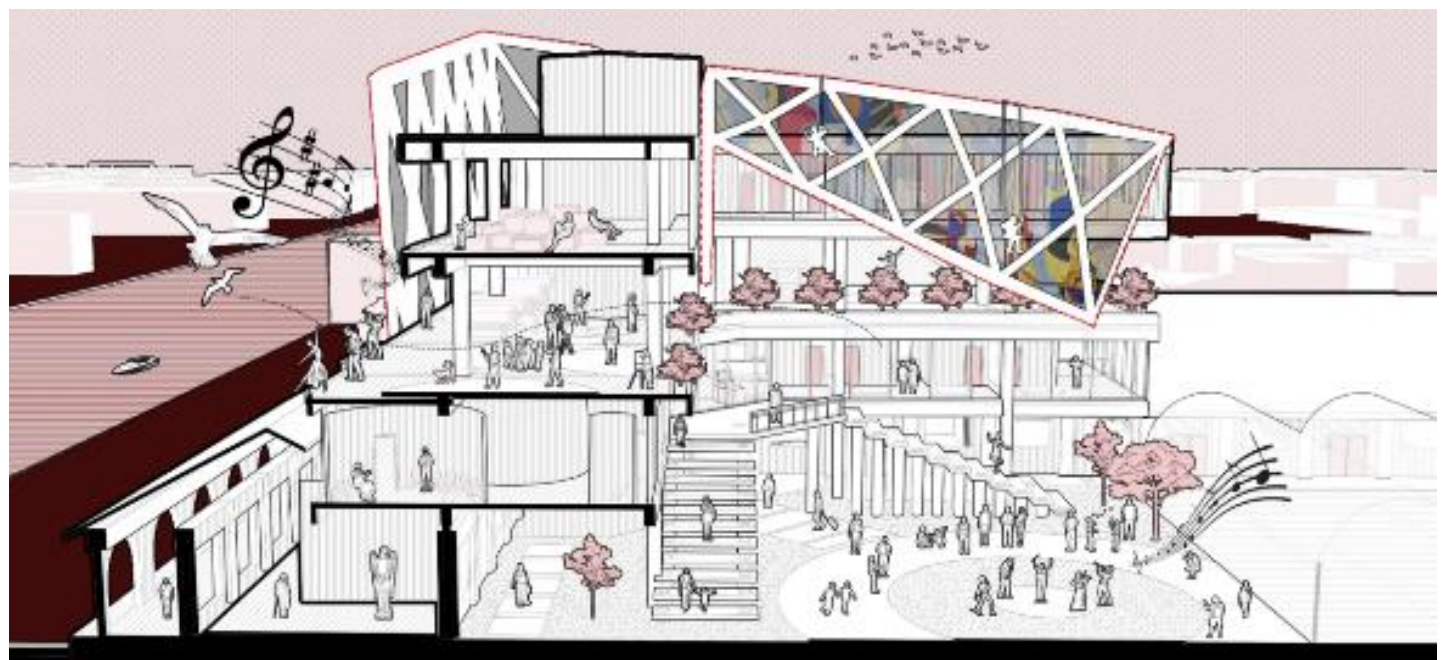

Gambar 9. Potongan Perspektif yang Memperlihatkan Segala Macam Aktivitas Sumber: Dokumentasi Pribadi, 2020

\section{Konsep Struktur dan Material}

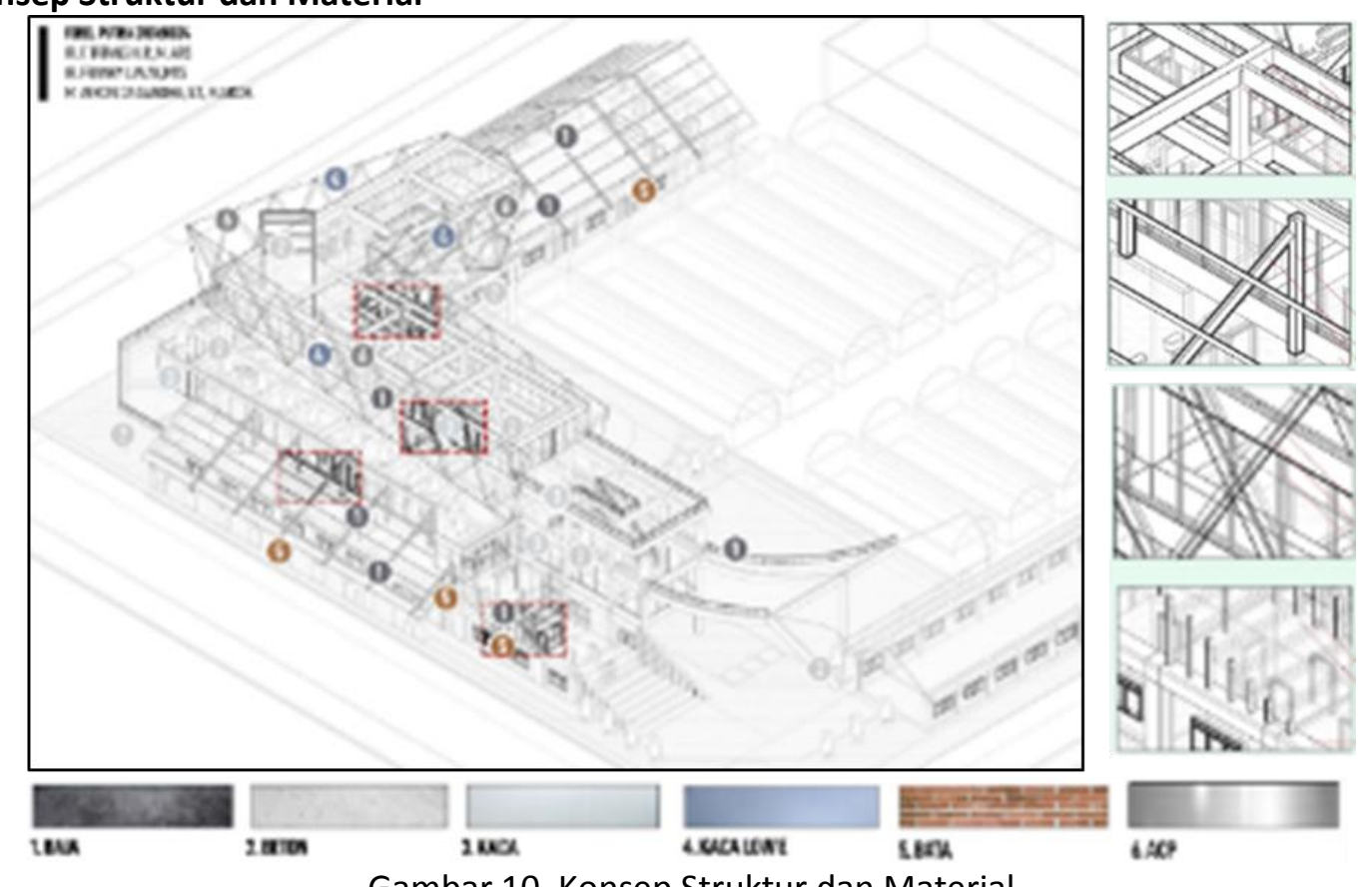

Gambar 10. Konsep Struktur dan Material

Sumber: Dokumentasi Pribadi, 2020

Sesuai metode, bangunan dibuat dengan menggunakan bahan-bahan yang mudah di dapat dengan struktur yang hemat. Bahan-bahan juga dipilih berpatokan pada massa bangunan yang cenderung rektangular. Bahan beton, baja, besi merupakan bahan-bahan yang mudah di dapat. Kaca mural terbuat dari low-e glass yang mengurangi radiasi matahari namun tetap fully translucent, dengan stiker yang melapisi sehingga proses penggantian mural menjadi lebih mudah. 


\section{Gambar Kerja}

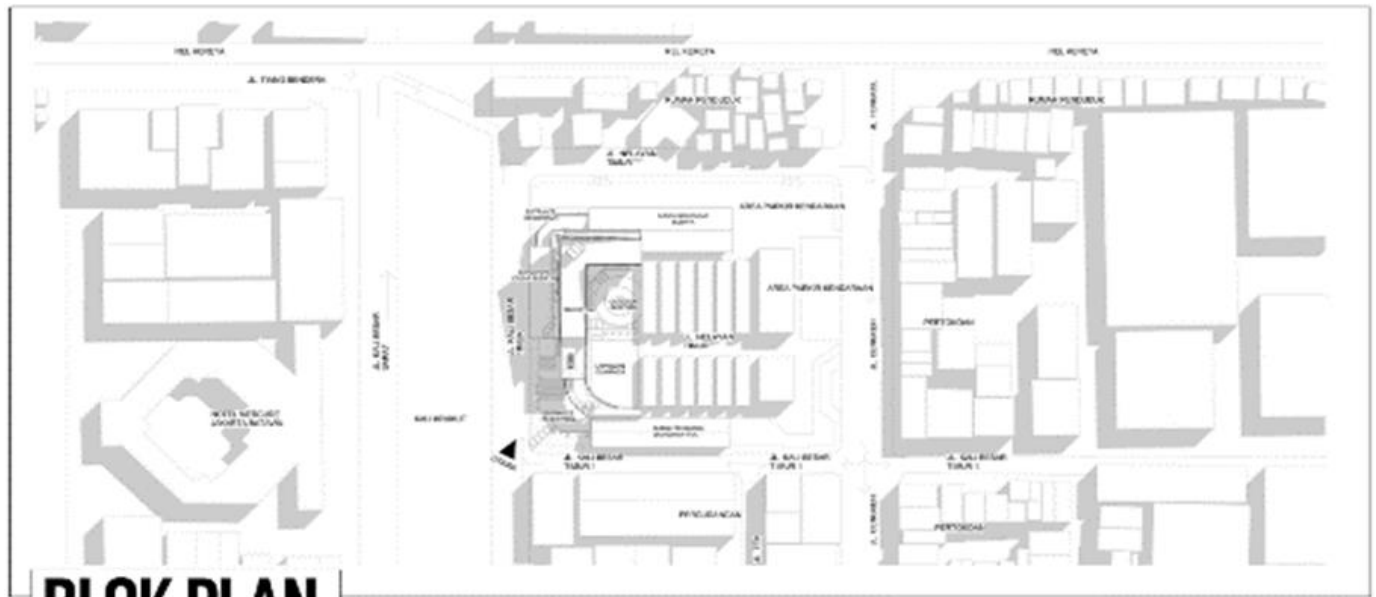

\section{BLOK PLAN}

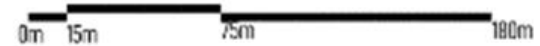

Gambar 11. Blok Plan

Sumber: Dokumentasi Pribadi, 2020

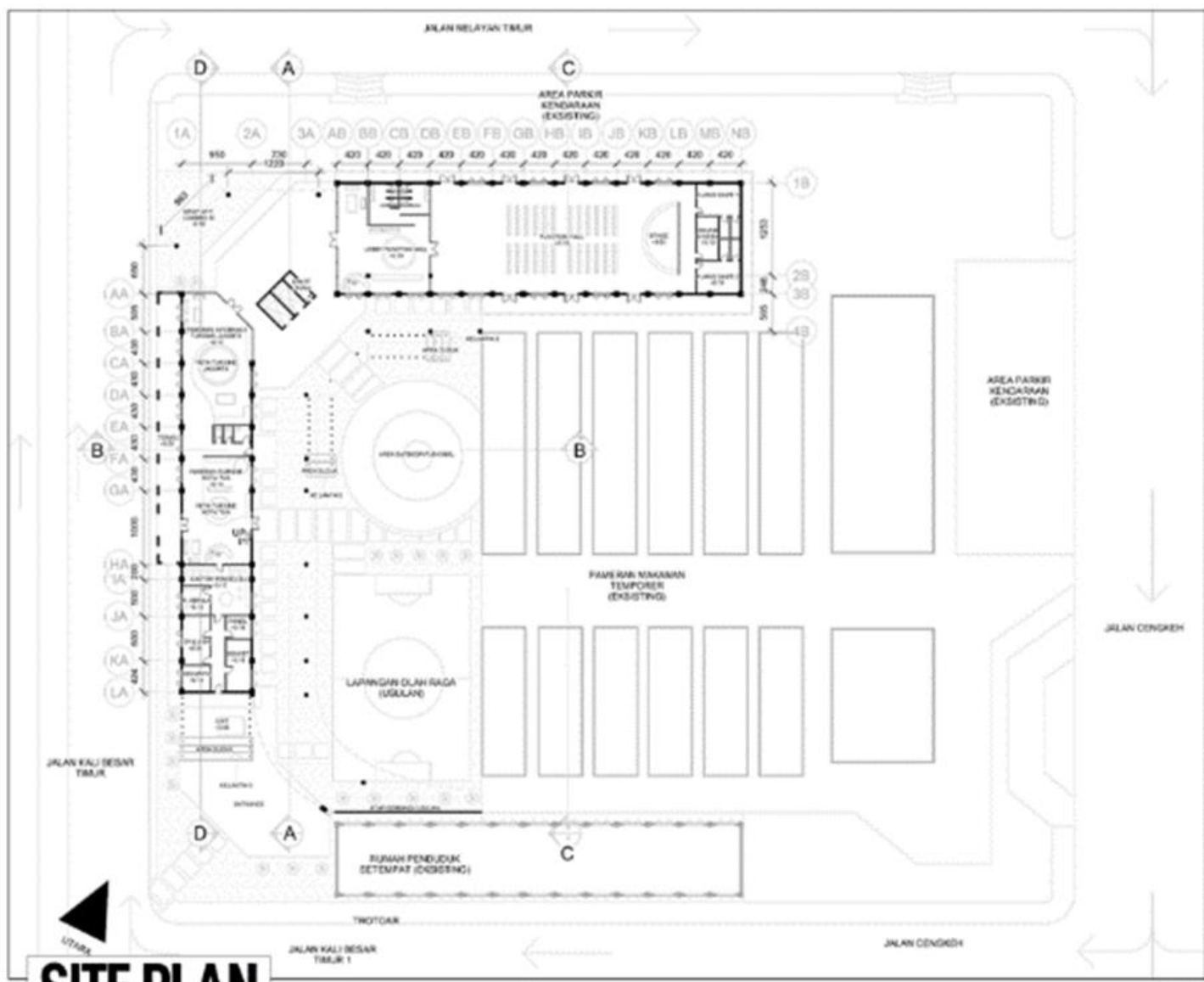

SITE PLAN
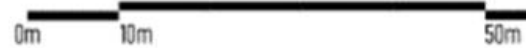

Gambar 12. Site Plan

Sumber: Dokumentasi Pribadi, 2020 


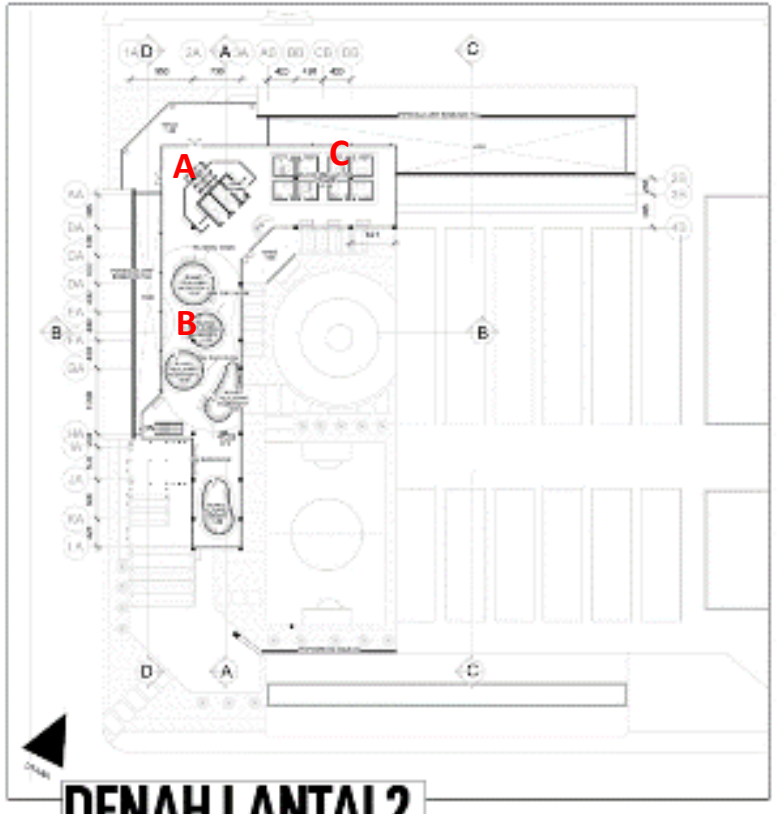

DENAH LANTAI 2

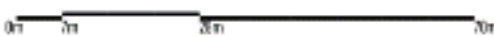

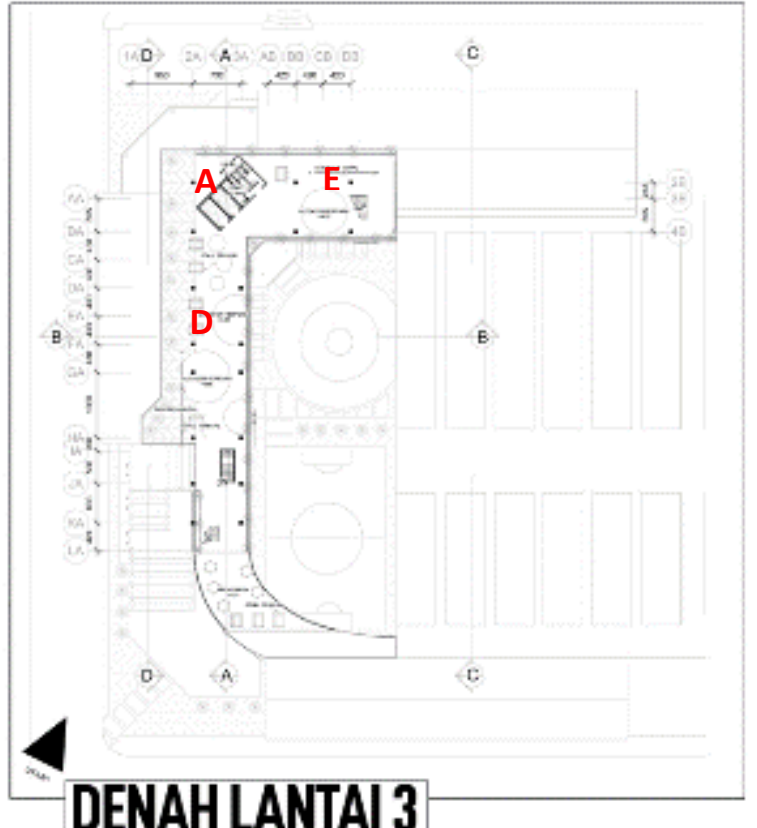

DENAHLANTAI 3

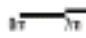

${ }_{\pi}$

Gambar 13. Denah Lantai 2 dan 3

Sumber: Dokumentasi Pribadi, 2020

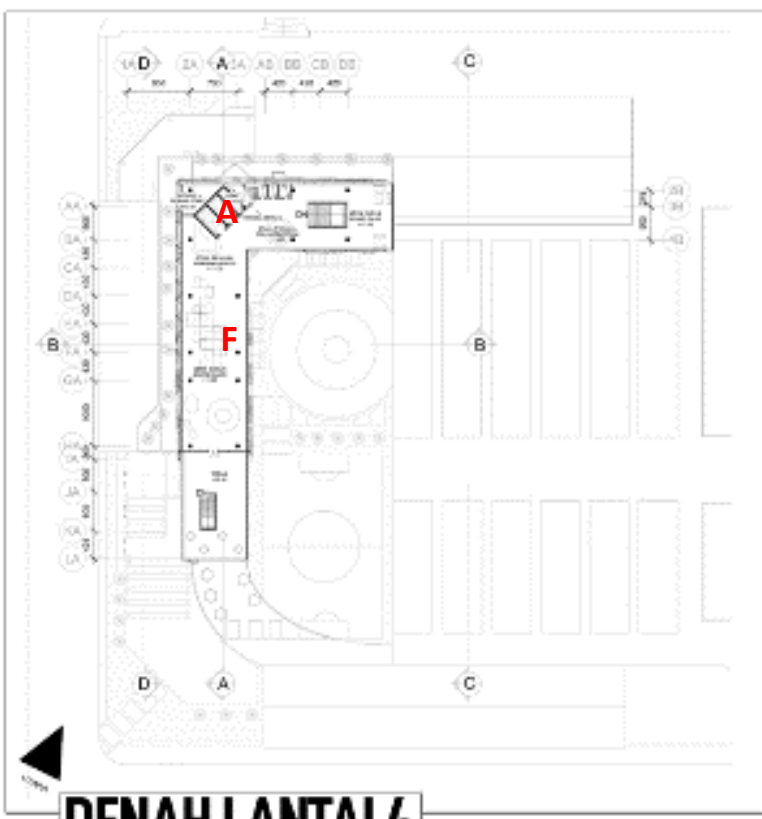

DENAH LANTAI 4

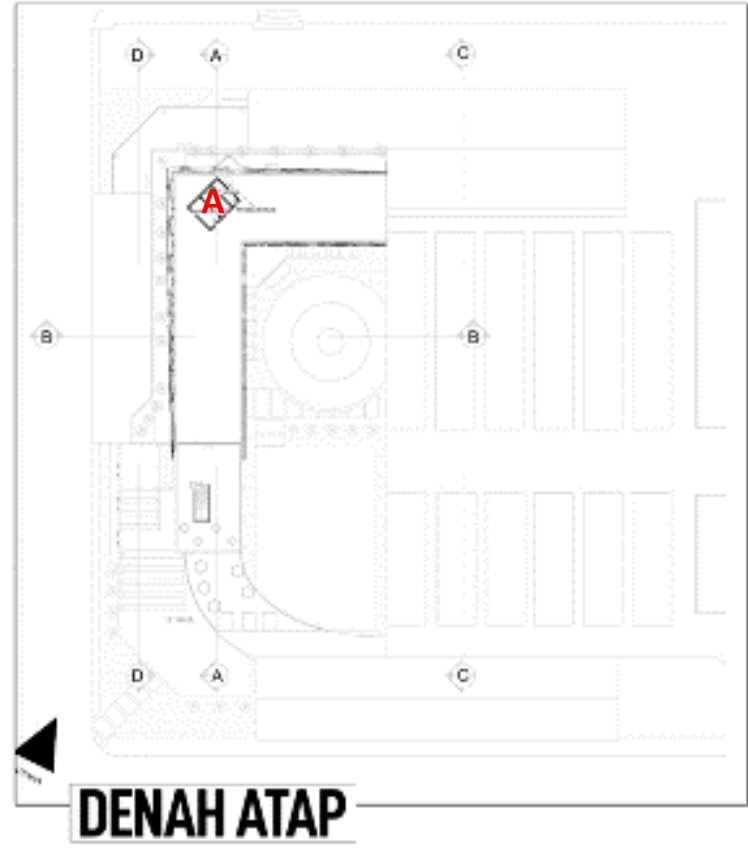

Gambar 14. Denah Lantai 4 dan Denah Atap

Sumber: Dokumentasi Pribadi, 2020

Keterangan:

A. Core, ruang lift, area servis (ruang panel, toilet, shaft utama)

B. Area edukasi musik kelompok (1 session lesson)

C. Area edukasi musik privat

D. Outdoor Perform

E. Stall produk-produk tradisional/lokal

F. Ruang hang out 


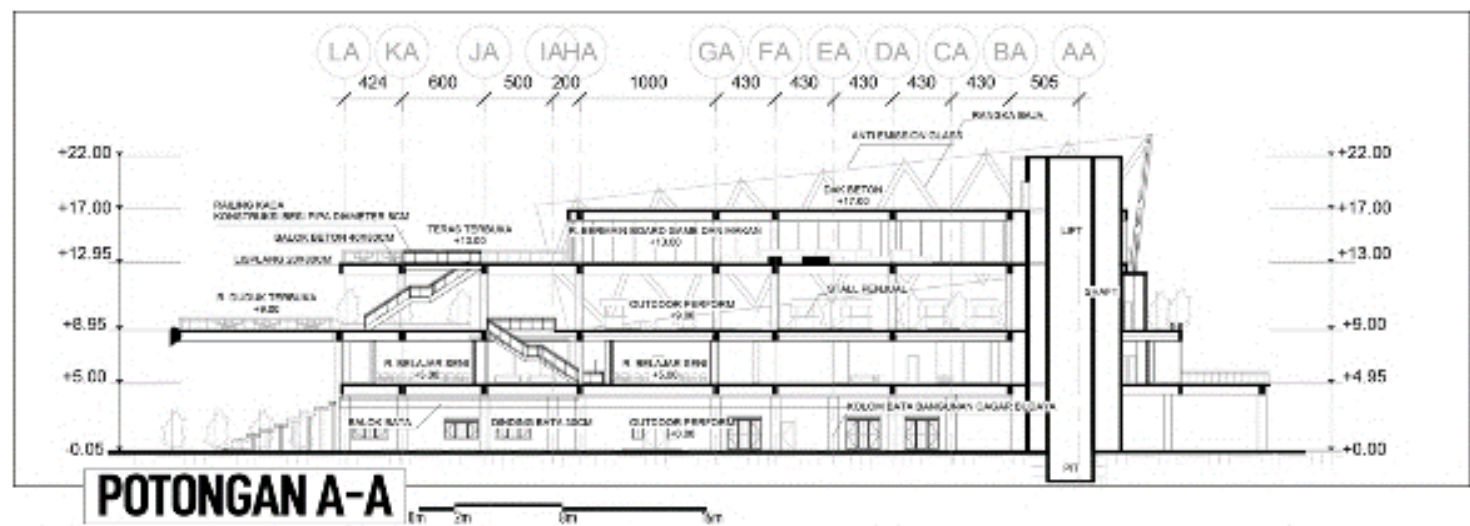

Gambar 15. Potongan A-A

Sumber: Dokumentasi Pribadi, 2020

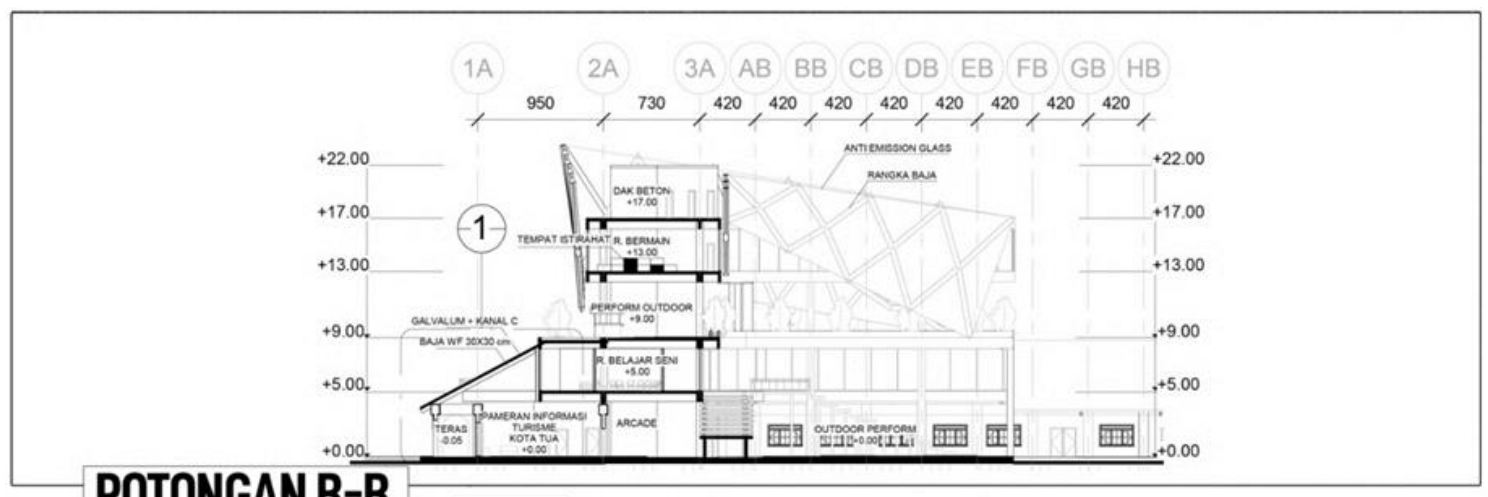

\section{POTONGAN B-B}

Gambar 16. Potongan B-B

Sumber: Dokumentasi Pribadi, 2020

\section{KESMPULAN DAN SARAN}

\section{Kesimpulan}

Pembangunan third pace dengan fokus memberikan wadah interaksi sosial yang interogatif dan mempersatukan kebutuhan warga masyarakat terutama bagi generasi 'internet' yaitu generasi millenial dan setelahnya. Hal ini sangat menentukan perkembangan manusiamanusia tersebut kedepannya dan tentunya akan berpengaruh pada kemajuan Kota Jakarta maupun Indonesia. Pada kasus ini, Kotatua merupakan sebuah tempat yang terkait dengan kehidupan banyak orang yang berlatar-belakang yang berbeda-beda, sehingga pembangunan third place yang dimaksud sangat dapat berguna dan tentunya diharapkan ada pembangunan third place berfokus ini di lokasi lain, third place yang tidak hanya menjadi tempat istirahat semata. Pembangunan third place dapat berbentuk apa saja asalkan memenuhi kebutuhan masyarakat setempat. Dalam kasus ini, wadah interaksi sosial dalam third place ini berwujud sebuah visitor center yang dibutuhkan oleh Kotatua Jakarta demi kemajuan kawasan Kotatua Jakarta sebagai kawasan wisata. Selain itu, third place harus dibuat sebagai bangunan yang low profile. Third place juga harus dibuat dengan kesadaran melestarikan identitas lokal dalam hal fisik maupun non fisik. Impact yang diberikan harus berdampak baik terhadap sustainability kawasan dalam hal material, ekonomi, dan komunitas, sesuai dengan Sustainable Development Goals yang ada. 


\section{Saran}

Kelanjutan dari studi yang sudah saya lakukan dapat diteruskan dengan membangun third place di lokasi lain yang juga didatangi pengunjung dengan jumlah yang banyak dan beragam. Hal ini bertujuan untuk menambah jumlah masyatakat yang dewasa, open minded, dan terbuka pada perbedaan-perbedaan yang ada di bumi ini.

\section{REFERENSI}

Anon. (2018), Bhabha's Hybridity and the Third Space in Postcolonial Discourse. Retrieved July 13 , 2020, from https://www.everettsd.org/cms/lib07/WA01920133/Centricity/Domain/965/Meredith.pdf

Bhabha, K., H. (1994). The Location of Culture. New York: Routledge.

Butler, M., S. (2016). "Third Places" as Community Builders. Retrieved July 13, 2020, from https://www.brookings.edu/blog/up-front/2016/09/14/third-places-as-communitybuilders/\#: :text=Third\%20places\%20build\%20communities\&text=One\%20commentator\% 20refers\%20to\%20third,\%E2\%80\%9Cliving\%20room\%E2\%80\%9D\%20of\%20society.\&text=T his\%20is\%20in\%20stark\%20contrast,contact\%20with\%20the\%20outside\%20community

Graham, A. (2014). How Social Media Makes Us Unsocial. Southern Methodist University: TEDx SMU.

Hidayat, A., Sjarief, R. (2019). Methodgram. Jakarta: RAW Press.

Levison, D. (2019). Open VS Closed Architecture. Retrieved July 13, 2020, from https://commissiontrac.com/the-difference-in-open-architecture-vs-closed-architecturetechnology-systems/

Oldenburg, R. (1989). The Great Good Place. Da Capo press: Boston

Originlab. (2019). Internet Growth Statistic. Retrieved February 7, 2020, from https://www.internetworldstats.com/emarketing.htm

Poerwanto, E. (2019). Kota Tua Dikunjungi Sejuta Wisatawan. Retrieved February 10, 2020, from https://bisniswisata.co.id/juni-2019-kota-tua-disambangi-sejuta-wisatawan/

Pratomo, Y. (2018). Jumlah Pengguna Internet di Indonesia Sampai 171 Juta. Retrieved February 6, 2020, from https://tekno.kompas.com/read/2019/05/16/03260037/apjiijumlah-pengguna-internet-di-indonesia-tembus-171-juta-jiwa

Salangkas, H. (2019). Perkembangan Teknologi Informasi. Retrieved February 6, 2020, from https://www.kompasiana.com/hanrinisalangkas8330/5d9f1bb7097f362d4468ae02/perkem bangan-teknologi-informasi

Sutanto, A. (2020). Third Place. Universitas Tarumanagara: Jurusan Arsitektur

Turner, B. (2017). The Third Place Is Changing. Retrieved July 13, 2020, from http://www.bctarchitects.com/blog/2017/5/18/the-third-place-is-changing 